\title{
8 Tower Hill State Game Reserve by Lisa Justin and Ian D. Clark
}

This chapter offers a historical analysis of the evolution of tourism at the Tower Hill State Game Reserve. Tower Hill is an extinct volcano and a major natural landmark located on the Princes Highway between Warrnambool and Port Fairy in South West Victoria. Today, the reserve is an important focus for tourism and protects a variety of environmental, landscape and cultural values. It provides visitors with walking tracks, picnic facilities, lookouts and the Worn Gundidj Visitor Centre is a venue for environmental and cultural interpretation.

A nested caldera, Tower Hill is one of the most recently active volcanoes in western Victoria (Downes, 1961:3). It measures $3.2 \mathrm{~km}$ by $2.4 \mathrm{~km}$ wide and is the largest of its type in Australia. The volcanic formation of Tower Hill comprises of a main crater with a surrounding tuff ring. The inner walls of the tuff ring are steep and enclose a flat-floored crater over 90 metres deep. Within the crater Tower Hill is divided into three scoria islands, and a permanent and semi-permanent lake. The reserve comprises 610 ha that are made up of three islands: Main Island (125 ha); Fairy Island (18 ha); and Hat Island (1 ha), and Tower Hill Bank (120 ha), and permanent and semipermanent water.

Parks Victoria (2012: 1) stated that 'the way in which the volcano was formed is of great interest to geologists'. The caldera was created 30,000 BC after a violent volcanic explosion, which created a funnel shaped crater (which later filled with water to create a lake), islands and a volcanic cone.

A change in the nature of the eruption led to the growth within the main crater of numerous small cones, built up of scoria and coarse volcanic fragments. These small cones are described as 'nesting' within the main maar crater. Several craters can still be seen in the small cones (Fisheries and Wildlife Department, 1983: 4)

It lies at the end of a line of thirty similar volcanoes, which extends from Colac to Port Fairy, and is part of the UNESCO-endorsed Kanawinka Geopark (Parks Victoria, 2012: 67).

The first confirmed European sighting of Tower Hill was by French explorers sailing with Captain Nicolas Baudin aboard the 'Geographe' on 31 March 1802. Francois Peron (1809: 245) has provided us with the earliest description:

As we continued our course along the shore we came ahead of a peak of a conic form, to which we gave the name of the Peak of Reconnaissance, and the nearest cape we called Tabor Cape. ${ }^{32}$

32 Downes (1961: 11) has identified Tabor Cape as the headland at present-day Warrnambool. Baudin's (in Learmonth 1934) account does not mention the Peak of Reconnaissance.

(c) BY-NC-ND Copyright (C) 2014 Selection and editorial matter: Ian Clark; individual contributors, their contributions This work is licensed under the Creative Commons Attribution-NonCommercial-NoDerivs 3.0 License 
Matthew Flinders also sailed along the southern coast of Australia and on 20 April 1802 in the ship's log referred to Tower Hill as 'Peaked hill, position uncertain'.

Tower Hill is situated within the traditional country of the Koroitgundidj Aboriginal people, who spoke the Peekwurrung dialect of the Dhauwurdwurrung language (Clark, 1990). Food sources were particularly plentiful in the fertile coastal area around Port Fairy and Tower Hill, with the western plains supporting the Aborigines' rich cultural life. For Aboriginal people the land was an intrinsic part of cultural and spiritual life, with natural features representing deep religious or 'dreaming' significance. Archaeological surveys of the area have uncovered axe heads and other artefacts in the volcanic ash layers indicating that there was an Aboriginal presence in the area before the eruption (Parks Victoria, N.D).

H.F. Wickham corresponded on the matter of Aboriginal people and volcanism in a letter to The Sydney Morning Herald on Friday 13 June 1902:

On this subject [of volcanic eruptions] Mr James Dawson says -"An intelligent aboriginal distinctly remembers his grandfather speaking of fire coming out of Bo'ok, a hill near the town of Mortlake, Victoria when he was a young man “ Another says -"When some of the volcanic bombs found among the scoria; at the foot of Mount Leura, were shown to a Colac native, he said they were like the stones which his forefathers told him were thrown out of the hill by the action of fire.” Again, at Tower Hill, in the same State, beneath a bed of lava, "tuff,' the skeleton of a dingo was found buried, now as the dingo is supposed to have accompanied man to Australia, and man is the most recent development of the countless stages in the great scheme of evolution, it follows that the eruption which overwhelmed the dingo is of modern date.

Geologist Edmund Gill (1938) has also discussed Aboriginal associations with volcanism in the region. He noted that the Aboriginal people had a tradition that their ancestors saw 'burning mountains' in the Western District:

Their description of a volcano as a "burning mountain" reminds one of the old description we were given at school "a volcano is a mountain which emits fire and smoke." The writer once heard a noted professor of geology comment upon that definition as follows:-"The definition is quite correct except that a volcano is not a mountain and it emits neither fire nor smoke. A volcano, strictly speaking, is a vent. It may exude molten lava, but it does not burn. The cloud of steam rising from the crater is often mistaken for smoke.

However, are we to give any credence to the aboriginal legend? Has Tower Hill been active since the district was inhabited by homo sapiens? Can the volcano's life history be written with any accuracy? The geologist, hammer a-hand, has chipped out a great deal of that story. Detectivelike, he has followed the clues of broken strata and yawning craters. He has examined the "finger-prints" of volcanic ash over the environing countryside. He has "reconstructed the crime," so to speak. And this is the dramatic story which he has spelt out from those rocks, a story which does not deny the aborigine his legend. ... Anyway, the Americans have a replica of Tower Hill at Crater Lake, in Oregon. That volcano also has been gutted. Like Tower Hill also it has built for itself a miniature mountain in the centre of the big truncated crater, and made that mountain an island by surrounding it with water. In recent years Tower Hill has lost most of its lake. It is reported that the tapping of spring waters for the supply of the nearby township of Koroit is the 
explanation of this diminution. The aerial photograph shows part of the sides of the original mountain. At the foot of this rim are the flats, which until recently were covered with water. In the centre are the younger cones and craters-the dying work of the volcano. The remaining area of lake is just out of the photograph to the right. In the fore ground are some of the very fertile fields near Koroit.

But to come back to the aborigines' legend. How is that substantiated? For this part of the story we need to go five or six miles away to the city of Warrnambool. This attractive city is built on dune sandstone, of which many of its buildings are constructed. Some years ago there was taken from this sandstone the impression of an aborigine and his lubra where they had been seated in the sand. In another place probable footprints were discovered. Chance was kind on these occasions and preserved these impressions for us. Now the ash from Tower Hill overlies this dune sandstone; therefore the volcano must be younger than these human impressions. Tower Hill must have been active after human beings came to live in that district. Further evidence is provided in the fact that the strata of volcanic ash at Koroit overlay a modern sea beach strewn with shells identical in species and condition with those now found thrown up in the vicinity at high tide. To this extent, then, the scientist can corroborate the ancient tradition of the aborigine (The Argus, 18/6/1938).

The Aboriginal association with volcanism is also confirmed by their name for Tower Hill (see below) which is suggestive of eruptive activity.

\subsection{First Phase: Sight Sacralization and Naming 1802-1891}

In terms of MacCannell's (1976) first phase in the development of attractions - that of sight sacralization or naming, numerous Aboriginal names have been recorded for the caldera which was known as Koroit and the many features surrounding it. The Dhauwurdwurrung or Gundidjmara Aboriginal clan associated with Tower Hill was known as the Koroitgundidj (meaning 'belonging to Koroit') (Dawson, 1881; Clark, 1990). Clan names were typically taken from named places, so the clan name indicates the Aboriginal name of Tower Hill. They were also known as the Kartgundidj (meaning 'belonging to mountain') which is a descriptive name akin to 'mountain people' and was probably conferred on them by other clans.

Aboriginal microtoponymy at Tower Hill has been examined by Clark (2009) in which he identified that some eleven place names exist at Tower Hill, for features as diverse as scrub, flats, craters, the crater's lake, and lake banks (See Table 8.1). All eleven names are sourced from the ethnography of James Dawson (1881), which was the result of extensive study of western Victorian Aboriginal languages by Dawson and his daughter Isabella, from 1844. 
Tab. 8.1: Aboriginal toponyms at Tower Hill

\begin{tabular}{|c|c|}
\hline Aboriginal Name & Meaning \\
\hline Tower Hill; Koroitj & $\begin{array}{l}\text { Possibly nettles (Dawson, 1870), or suggestive of volca- } \\
\text { nism (Mulder, 1909: 11); note, local clan is Koroitgundidj } \\
\text { (Robinson Jnl, 24/3/1842 in Clark 2000b). }\end{array}$ \\
\hline Tower Hill - scrub; Murrheaal & $\begin{array}{l}\text { Scrub between Tower Hill Flat and lake (Dawson, 1881: } \\
\text { ixxxi). }\end{array}$ \\
\hline Tower Hill Flat; Taerra Mukkar & $\begin{array}{l}\text { Sweet root like a parsnip; West side of Tower Hill Flat } \\
\text { (Dawson, 1881: Ixxxii). }\end{array}$ \\
\hline Tower Hill Flat - scrub; Yaal & Scrub on West side of Tower Hill Flat (Dawson, 1881: Ixxxi). \\
\hline Tower Hill Island; Parrang Kuttcha & $\begin{array}{l}\text { Name of an edible root found there; The island surrounding } \\
\text { by Tower Hill Lake, once joined with the sea (Dawson, 1881: } \\
\text { Ixxxiv). }\end{array}$ \\
\hline Tower Hill Island - crater; Yatt mirng & White eye; crater in Tower Hill Island (Dawson, 1881: Ixxx). \\
\hline Tower Hill Lake; Kurruk baruum & $\begin{array}{l}\text { Grandmother of lice; outlet from Tower Hill lake (Dawson, } \\
\text { 1881: Ixxx). }\end{array}$ \\
\hline Tower Hill Lake; Mitjil & Mitj = skin (Dawson, 1881; Ixxx). \\
\hline Tower Hill Lake - bank; Koroitj & West bank of Tower Hill Lake (Dawson, 1881: Ixxx). \\
\hline Tower Hill Lake - bank: Mum ngamat & $\begin{array}{l}\text { Bottom of the sea; East bank of Tower Hill Lake (Dawson, } \\
\text { 1881: Ixxxi). }\end{array}$ \\
\hline Tower Hill Lake - outlet; Kuuro baruum & $\begin{array}{l}\text { Grandmother of lice; Outlet of Tower Hill Lake (Dawson, } \\
\text { 1881: Ixxx). }\end{array}$ \\
\hline
\end{tabular}

The Dhauwurdwurrung Aboriginal name for Tower Hill is Koroit which survives in the nearby township of the same name. According to Dawson (1870), the name is suggestive of volcanic activity; and Mulder (1909: 11) has suggested it means 'smoking, hot ground'. As well as the archaeological record, toponymic analysis confirms Aboriginal presence during the last eruption (Downes, 1961: 5).

The first European name for Tower Hill was 'Peak of Reconnaissance' conferred in 1802 by the French exploration expedition led by Nicolas Baudin. The expedition included the cartographer-surveyor Louis-Claude De Freycinet and the naturalist Francois Peron. A few months later, Matthew Flinders' exploration party simply named the caldera 'Peaked Hill'. Given European discovery and naming of Tower Hill in 1802 ('Peak of Reconnaissance'-a name that did not survive in local parlance), Downes has suggested that Tower Hill would have served as a landmark for ships entering Port Fairy and Warrnambool, and although there was much maritime activity along the southwest coast over the next thirty years, few records survive and no direct references to Tower Hill by these seamen have been found. Downes posits the first examination of Tower Hill by land must have been by men employed as sealers and whalers along the southwest coast. He believes it probably first became known to land travellers in 1839 (Downes, 1961: 16). 
Downes believes the popular name 'Tower Hill' came into use in the early 1840 s, although when he conducted his research the earliest formal use of this name that he could find was Pickering (1846). In April 1841, the Chief Protector of Aborigines in the Port Phillip District, George Augustus Robinson, visited the Port Fairy district, and his private journal reveals that the eminence on the edge of the swamp was called by 'Campbell's men “Tower Hill”'. Campbell is a reference to Captain Alexander Campbell, who was in partnership with John Griffiths and Michael Connolly in an agricultural enterprise on a stretch of land extending from Killarney to the Hopkins River from 1838 until 1842. Robinson's reference provides us with a date of usage of 1841 (and possibly earlier), and infers that it was the name used by station employees, and possibly conferred by them. Downes considers that Tower Hill is a descriptive name, and posits that the volcanic formation may have resembled a castle complete with a moat and steep walls, hence the name. Anita Brady (1992: 2) has offered a second explanation: 'Another account credits Dougald Langtree, a sailor from Glasgow with naming the site after Tower Hill in Scotland'. Presumably Brady is referring to Tower Hill, overlooking Gourock on the Clyde coast.

When Robinson learned of Tower Hill on 28 April 1841 he also learned that a 'native village' was to be found there. He learned that 'There is a large swamp on the east of the Port Fairy river where the natives get their chief support, roots, \&c., and near to a small eminence on the edge of this swamp, called by Campbell's men 'Tower Hill', is a native village: an assemblage of huts \&c. Along the coast near to the shepherds huts are reefs of rock abounding with the haliotus mutton fish, muscle [sic], moreover crawfish and which must have afforded them a good supply as the camping place of the natives in the beautiful forest of dwarf banksia abound with cinirated shells' (Robinson Jnl 28/4/1841 in Clark, 2000a).

The area around Tower Hill was largely ignored by squatters because its rich volcanic soil supported dense vegetation. They were looking for open grazing land and the land around Tower Hill was too thickly forested (McCorkell \& Yule, 1999). Between August and December 1840, Tower Hill was incorporated into an extensive pastoral run held by the Bolden brothers (Armyne, George, and Lemuel). In November 1841 William Rutledge purchased part of this run for a special survey. In 1843 the Ryrie brothers (Alex and William) took over the Lake station from the Bolden brothers, and Tower Hill was its central feature. In 1844 Jack Buchanan was listed as the license holder. Rutledge is listed as the station holder from 1849 until 1851.

Richard Hoddle, who carried out the first parish survey in 1845, described the area as having chocolate covered soil of the richest description (McCorkell \& Yule, 1999). Reports such as this brought the earliest pioneers to the district to clear the forest and establish farms. The soil from Tower Hill determined the pattern of settlement and the development of Koroit (McCorkell \& Yule 1999). Little was recorded of Tower Hill until a map was compiled from surveys done between 1846 and 1850. The surveyors confirmed that the land rising toward the banks of Tower Hill was heavily 
timbered with thick forests of stunted gum and a heavy undergrowth of ferns and native laburnum.

In the 1850s, the Midgley family settled at Yangery Creek near Tower Hill and lived in tents until they hacked out of thick bush a suitable plot to build their home. Sarah Midgley described the view from their tents as 'that desolate spot surrounding with dense scrub, stringy-bark and gum trees, black wood, wattles and not a single house within a mile' (McCorkell \& Yule, 1999: 1).

During October 1854, Dr W.H. Harvey, an Irish botanist, visited the district, and recorded his impressions:

On reaching the steep bank of the lake we looked down 200 feet into what must have been an extensive crater in old times, but now is partly a lake and partly a marsh. In the midst is a wooded island, rising like a cone 300 feet above the lake. There are two or three summits in which there are said to be small craters. The borders all around the lake have similar marks of volcanic origin and all are beautifully wooded. We had only time for a hurried scramble down the steep side of the lake; and the ground being covered with rich grass I got but few flowers, but among them was a beautiful Ajuga Australia, a fairy violet, a nettle and an indigo. On the waters of the lake myriads of a little floating fern, looking like duckweed, were swimming. The name is Azolla. For its size which is only inches across, it is extremely pretty (Lucas 1933: 187 in Downes, 1961: 31f).

Tim Bonyhady reported that 'Pteridimania'-as the fern craze was known from the 1850s in both England and Australia - was fuelled by the size of Australian ferns, which convinced colonists and visitors alike of the 'comparative insignificance' of their English counterparts. A rare dissentient was Irish botanist Dr W.H. Harvey, who failed to satisfy his sister's 'fern fever' while visiting Tower Hill in Victoria's Western District in 1855. But the fault was with Harvey. Had he made his way from the outer banks of the volcanic crater to the islands in its middle, as James Bonwick did two years later, he would have found 'gigantic ferns' forming 'delightful bowers and alcoves' (Bonyhady, 1987: 104).

In 1855, James Dawson, of Kangatong, commissioned German landscape painter Eugen von Guerard to paint Tower Hill (see Fig.8.1). Bonyhady has noted that 'Like many successful pastoralists, James Dawson wanted paintings of both his own property near Port Fairy and the most notable feature in his local landscape-Tower Hill, which he described as 'one of the most beautiful and interesting specimens of an extinct volcano in all Victoria' (Bonyhady, 1987: 76). The painting entitled 'Outlook' depicted a variety of flora and fauna which had virtually disappeared by the end of the 1860s due to the clearing practices of European settlers who used the local soils for agriculture and who grazed cattle on the islands.

The people who commissioned von Guerard to paint homestead portraits were, of necessity, successful landholders, usually with substantial if not grand houses. The owners of small houses and bush huts typically could not afford to buy oil paintings. Nerveless such, houses, especially when set against a background of virgin forest or dramatic mountains were a popular subject 
with many colonial artists because they could be used to convey the idea of the pioneer in the wilderness, the taming of the land (Bonyhady, 1987: 76).

Von Guerard's preferred subjects were fern tree gullies, waterfalls, rocky coastal scenes and views from mountains as well as sweeping views from mountain tops. In these pictures he was concerned to convey the grandeur of Australian scenery. He also sought to convey the magnificence of God's creation; as he put it: 'to catch now and then a glimpse of the divine poetical feelings' inspired by nature (Bonyhady, 1987: 357). But most of all von Guerard 'wished to paint as closely as he saw the details and effects of nature' as he stated:

If ever [he] could succeed to paint Australian scenes to make them delightful illustrations for treatises of botanical or geological features of the colony then he would be convinced that for the future his paintings would be a greater value, where it would be doubtful if those which can be taken equally well for a misty English or an Australian landscape will have the same future (Bonyhady, 1987: 357).

His painting was later to feature prominently in the Tower Hill story and since 1961 has been used as the basis of a revegetation program entailing 300,000 plantings.

The educational inspector, James Bonwick, visited the district in 1857 and in his 1858 publication he gave a detailed account of the locality. He was clearly impressed with the wonders of Tower Hill:

Tower Hill is the most interesting locality I ever visited, and I am indeed astonished that the people of Melbourne and Geelong generally should be ignorant of its wonders. It is an island or rather three islands together encompassed by a wall in the shape of a circular ash-bank, with water, a moat, inside and around. Something similar is known in the Phillipine islands, where an island of cinder and scoria springs nine hundred feet high from the body of Lake Taal. Tower Hill district is essentially a farming one. Immense crops are raised, though the land is chiefly leasehold portions of Rutledge's survey. Some portions of the Tower Hill bank have been sold lately. The settlers appear to be Irish or Scotch, there being few English. There is no township, though a road-side inn is erected for the convenience of travellers (Bonwick, 1858: 70).

The surveyors had some time before constructed a crude bridge across the swamp between the banks and island, in order to transport a suitable pole for the summit of their Trigonometrically [sic] Station. The straw which they had spread over to fill up the gaping chasms has furnished many meals for straggling bullocks by the lake; so that in passing I had to make sundry leaps over and into moist places. On my first morning visit I ascended the Mount, being accompanied by the Rev. Mr Baker, an old traveller, and an expert mountaineer. Upon the next occasion, when alone, I walked around the base of the island, which with the indentations of its bays, I should imagine to be nearly five miles in length, although it is said to contain but eight hundred acres (Bonwick, 1858: 75).

There was one perpendicular block of cinder, thirty feet in height, presenting some remarkable aspects of the volcanic agency; the sulphur, if any, had sublimated. Well might the natives exclaim as they saw this,-'Big one fire sit down along here.' What a gorgeous sight must have been witnessed by unsentimental kangaroos of old when Tower Hill was in full blaze! Doubtless 
the hopping tribe were peacefully nibbling when rumours of war's alarms arose. The rumbling of earthquakes shook the rock below. Steamy vapours pierced the rust of limestone (Bonwick, 1858: 76).

Although Bonwick spent little more than two hours exploring Tower Hill, his comments are significant for in his closing remarks he called for the reservation of Tower Hill:

A stroll among the gigantic ferns of the valley, or a ramble among the cones and craters, has peculiar attractions. But these are not comparable to the winding path at the foot of the basaltic rises close to the lake. There the graceful Fern tree waves, ... almost tropical reeds rustle in the breeze, ... leafy shrubs and trees form delightful bowers and alcoves, and tender emotion in suitable company, will receive as genial and as rapid a development. The various impediments arising in the walk, such as the straggling roots, little inlets, tangled foliage, and jutting rocks, will only present occasions for the office of service, and the acceptance of kind assistance. Let the few who value sentiment in the colony [who] sympathize with nature, who love an undisturbed communion with the grand and sublime, join one and all in securing for themselves and posterity the authorised declaration, that Tower Hill shall be an everlasting reserve (Bonwick, 1858: 77).

\section{The Ballarat Star published an account of a visit to the site in December 1869:}

The steep pathway down to the lake and the crossing to the island present an unusually lively aspect as gaily dressed groups were making their way to the island. A tent was erected in which the refreshments were stored under the direction of Mr Maltby of Koroit, who supplied them; but these were largely supplemented by contributions of hams, roast lambs, fowls and cakes from the ladies of members of the society. The officers of the Warrnambool St. Patrick's Society were specially invited on the occasion and were accompanied by a number of their leading townsmen. Among the visitors were some of the leading mercantile men of Belfast [Port Fairy]; and it is almost needless to say that numbers of the farmers of the district and their families joined in the festivities. About half past four, the officers in their regalia (green velvet collars richly trimmed with gold lace), accompanied Mr Deegan to the summit of the island, followed by a large assemblage (The Ballarat Star, 17/12/1869).

The Australian Sketcher with Pen and Pencil (1/5/1877) gave an account of Tower Hill for its readers:

Tower-Hill, half way between Warrnambool and Belfast, is one of the most remarkable extinct volcanoes in the colony, and, according to Mr Rawlinson, who has studied the geological formation of that district, has played an important part in forming the coastline about Warrnambool. The following descriptive particulars are from The Argus report of a paper read by Mr Rawlinson before the Royal Society on the $14^{\text {th }}$ June last: "Tower Hill is an extinct volcano of great extent and is so named from the likeness to a peak or tower of the central cones of eruption, which form an island in the middle of what is now a large lake of water. The circumference of the main crater is from five to six miles, and although not more than $320 \mathrm{ft}$ deep at present, it was when in activity and before the formation of the cones of eruption a yawning chasm, of probably $600 \mathrm{ft}$ to $1,000 \mathrm{ft}$. ... Some years ago the cones were covered to the summits with trees, but over the greater part nothing but the trunks now remain. The high peaks are seen from a considerable distance at sea, and form a conspicuous landmark for vessels making the ports of Warrnambool and Belfast. 
The Rev. H.M.R. Rupp lived at Koroit from 1876 until 1884, from the age of 4 to 11 years, and in his reminiscences he recalled how when a child, 'My father used to lead visitors up to the brow of the gently rising hill behind Koroit with their eyes closed. What exclamations there were when they were opened on the summit!' (Downes, 1961: 76).

The Illustrated Australian News reported on Saturday 29 June 1881 'The great object of interest to the traveller on the way to Belfast is Tower Hill., the highest peak in a cluster of hills that rise from Lake Koroit which is itself the bed of an extinct crater. Looked at from any point of view this wonderful formation is a striking and interesting example of nature's handiwork. What is now the lake was once the basin of the volcano. In many parts the lake is shallow and a wild rank vegetation springs out of the water, making it a glorious haven for lacustrine birds'.

The Illustrated Australian News (21/3/1883) confirmed that the Western District of Victoria has many claims to the picturesque, and noted that 'the well-known Towerhill is one of the prettiest places that can be visited by the excursionist'.

A drive from Warrnambool on a well-made and even road of about 9 miles, passing over the Merri-bridge, through the village of Dennington, leaving Werronggort, the estate of Mr Thomas Rutledge, on the left, and Farnham, that of Mr. William Rutledge, to the right, brings the visitor to that magnificent piece of landscape scenery known as Tower-hill Lake and Island, nearly half way between Belfast and Warrnambool. This island is estimated to contain 1200 acres. It rises to a height of 350 feet and is separated from the main land by the lake which varies in width from 300 to 1000 yards. The lake is circular in form and has evidently been formed by volcanic action; small volcanic craters may also be seen on the island. Excepting a small portion on the west side, the lake is surrounded by steep banks rising to the height of from 200 to 300 feet. The island has been permanently reserved, and a committee of management for its improvement has been appointed. The locality is a place of popular resort with those in the neighbourhood, and picnic parties are frequent during the summer season (Figure 8.2).

Julian Thomas aka 'The Vagabond' was another who visited the natural attraction and an account of his impressions was published in The Argus of Saturday 13 December 1884:

I have heard a good deal of the drive around Tower Hill. I am not at all disappointed with my personal inspection of the locality; indeed I question if the natural beauties and material advantages of the country have been sufficiently magnified. ... A 13 miles drive from Warrnambool, and we are on the banks of Tower-hill lake. This is six miles in circumference, deep in some places, and abounding in eels; sedgy and marshy in others the banks bordered with reeds and dead gum trees. The extinct volcano is an island or rather three islands in the centre of this lake or moat which has been formed by the wall of ashes thrown up by the active crater, the accumulation making a circular bank almost as high as the volcano itself. This enormous fosse first became a marsh by the drainage from the surrounding eminences, and they many years back, Mr McCarthy having thrown the water back by an embankment at its outlet towards the Moyne, the lake as it now is was formed. The island is a public reserve of some 600 or 700 acres, a temporary crossing place making it available for tourist and picnic parties. Climbing the hills, one can study the old caters or inspect the small pool-a miniature edition of "Paradise Lake" on the island of Wanaka New Zealand. Or strolling through the little plains, valleys and dells one can speculate what a 
charming place this must have been before the larrikins from a distance amused themselves by setting fire to the grass and dry ferns. All the timber has been killed by this and the dead gum trees, gaunt and weird are, perchance in accord with the ancient spirit of destruction - the fire which was belched forth. But to the lover of nature this is a sad chance since when in $1857 \mathrm{Mr}$ Bonwick described the island "there the graceful fern-tree waves; almost tropical reeds rustle in the breeze, and leafy shrubs form delightful bowers and alcoves". The geologist of the present day will however be fully satisfied with his visit to the island of Koroit and the opportunities there given for studying the varieties of volcanic action.

In 1886 English geologist, Dr John E. Taylor, visited Australia and published an account of his holiday in Australia. Taylor (1886: 193) wrote very positively of Tower Hill: 'It is trenched all round with water, which occupies the depression, and thus gives to this hill a most remarkable scenic appearance. Tower-hill alone is worth going to see'. Another favourable account was published in The Argus (12/8/1891):

The beauties of the Tower Hill Lake an extraordinary volcanic formation on the sea coast between Warrnambool and Port Fairy -are vast. Many of the trees on the hill have been burned down or otherwise destroyed and the place has now a comparatively desolate appearance, even the wild fowl having deserted it. The borough council of Koroit is stirring in the interests of sport, and the secretary of Trade and Customs has received communication from Mr Richard Laffan, the local town clerk requesting that a proclamation should be issued prohibiting shooting on the lake. $\mathrm{Mr}$ Laffan states that the lake was formerly the resort of all species of aquatic wild fowl, but sportsmen have succeeded in driving them away.

\subsection{Second Phase: Framing and Elevation 1866-1892}

MacCannell (1976) stated that Elevation occurs when an object is put on display- in Tower Hill's case this is represented by its opening up for visitation. Framing is the placement of an official boundary around the object of interest. Two types of framing occur: protecting and enhancing.

The Bolden brothers, Armyne, George and Lemuel, were the first white settlers to use Tower Hill for grazing. They held licences for extensive runs in the area, including open forest and low flats of the formation. Tower Hill continued to be licensed for grazing runs until the 1850s, when Crown land allotments around the formation were sold. Many of these new freehold blocks extended to the rim of the crater and down the bank to the water's edge. Only small areas of Tower Hill remained in public hands in the period before the site was declared a reserve for public purposes in 1866.

In the early years of European settlement much of Tower Hill's natural vegetation was cleared and the land used for farming and quarrying. By the 1850s blocks of land were being leased and sold right down to the edge of the lake and land use became more intensive. The remaining timber was cut down and used for fuel. Early settlement at Koroit was scattered around Tower Hill, with two churches and a cemetery located on the south and south-eastern banks. Rutledge's Special Survey to the south 
of Tower Hill, where farming land was only available through leasehold, restricted development in that direction. Settlement to the north eventually became the township of Koroit. By the end of the 1850s more intensive use of the site was underway. The banks, including the steeper slopes, were cleared and planted with crops. A regime of clearing and burning was introduced, to promote pasture for livestock and areas for cultivation. Any remaining timber was removed, for fuel or firewood purposes. This use of the site was not restricted to the freehold land but included the island and those parts of Tower Hill which were reserved in 1866. The leased Crown land was subjected to frequent burning, to control the bracken and scrub regrowth, and rabbits flourished in the scrubby vegetation.

The Argus (16/9/1865) reported on the progress surrounding a request for a reservation at Tower Hill:

The Minister for Lands acceded yesterday to a request made by a deputation from the residents of Koroit that a site should be reserved for a district recreation ground and botanical garden. Mr Grant also accepted the nine gentlemen who had been nominated as trustees. He likewise expressed his willingness to allow the island in Tower Hill Lake to be used for acclimatisation purposes, but he intimated that a formal written application would have to be made as it would be necessary to impose conditions that timber should not be cut, and that rabbits and other burrowing animals should not be placed on the island.

Although there had been interest for many years in preserving Tower Hill, it was not until 1866 that the island, the lake and the two-fifths of the banks which still remained as Crown Land were declared the Tower Hill Acclimatisation Reserve, under the control of the Tower Hill Acclimatisation Society. The public land reservation formed an area of 597 hectares. The Tower Hill Acclimatisation Society was expected to be self-sufficient and in order to achieve this they raised funds for fencing and the appointment of a Ranger. The society allowed timber extraction, grazing and clearing and let people live on part of the reserve, further contributing to the degradation of the vegetation. However, the members believed in its 'improvement' through introduction of European birds, animals and plants which later brought disastrous results to the reserve. In keeping with its aim to introduce exotic plants and animals they planted exotic trees and introduced rabbits, goats, jungle fowl and pheasants. The first permanent crossing to the island was completed in 1867. Crops of this period included mangolds (a kind of beet) planted on the island, potatoes and onions. For many years numbers of poor families had lived on the sloping banks, building small shanties or living in tents. Many of these had vegetable patches, raised cows and sometimes rented their blocks from the Acclimatisation Society.

In February 1868, a caretaker was engaged at a salary of $£ 12 / 6$ per week. He and his wife lived on the island in a tent for a year. His duties were to burn off the underwood, to care for stock, to keep persons from trespassing and preventing them from removing any of the animals and fowls that were placed on the reserve (Downes, 1961: 46). These included two angora and six common goats, five jungle fowl, three 
pheasants and two rabbits. It was commented at the time that the goats had effectively cropped all the young gum trees. For a time the island was used as a common where the fee for pasturing a horse was $1 /$ - per week, a cow $6 \mathrm{~d}$, with foals and calves under six month free (Downes, 1961: 5). A survey of 1870 described 11 huts located on Crown land.

In November 1871 the Board of Land and Works approved the proclamation of Tower Hill Island of some 400 acres to be a reserve for the preservation and growth of timber called the Tower Hill Island State Forest, gazetted on 17 May 1872 (Downes, 1961: 54). On 8 September 1873, 1,475 acres comprising the Tower Hill lake and island were permanently reserved as a site for public recreation purposes (Government Gazette, 25/7/1873, p.1319, and 19/9/1873, p.1651).

Quarrying on Tower Hill began in 1878 with the removal of a small amount of tuff for what seemed a good reason-to make paths within Tower Hill Cemetery. By 1894 there were seven quarries around the site, including three within the Reserve. Quarrying on the island finally ceased in 1941, but continued on the banks. Over the next eighty years several hundred thousand cubic yards were removed until quarrying was stopped within the rim of Tower Hill in 1961. One private quarry on the southern rim was still being worked in 1966, although efforts were made to prevent the destruction of this unique area. Exposure of the volcanic layers brought about through quarrying has enabled scientists to study the Tower Hill formation more easily.

In the 1880s Koroit Council, then Committee of Management, permitted local ratepayers to depasture livestock on the Reserve. Cultivation was still permitted, on condition that the cleaning of scrub and bracken continued. There were still at least six families living on the lands in 1883, growing potatoes and oats, maintaining vegetable gardens and grazing livestock.

The Argus (11/7/1882) reported 'a telegram made from our Koroit correspondent, published in The Argus of yesterday stated that the Lands department had handed over the control of the Tower Hill reserve to the Belfast Borough Council. There appears to be a wrong impression in the district as to the action of the department. The management of the Tower Hill reserve has not been interfered with. The mistake appears to have arisen from the fact that the Belfast town common has been placed under the control of the local council'.

In its original state Tower Hill abounded with vegetation and wildlife. However it is obvious from just a few comments recorded by early pioneers and visitors, how quickly European settlement transformed the area. Tower Hill had become a monument to the general destruction of wildlife habitat caused by intensive and unplanned agricultural development of much of Victoria. Historically and pictorially, these changes and their sequences are documented very well at Tower Hill. The influx of settlers about this time, many from the goldfields, led to a rapid change in the appearance of Tower Hill. Paintings and photographs from the earliest period in 1887 show the method of destruction; burning, grazing and cutting for firewood had by this time removed all timber of any size. After good wildlife conditions were replaced by a uni- 
formly poor vegetation of bracken and grasses, there was a dramatic reduction in the numbers and variety of wildlife. (Downes, 1961: 5)

When James Dawson revisited Tower Hill in 1891 he was disgusted with what he saw, a landscape degraded by clearing, grazing, timbering, and the introduction of exotic plants and animals. He discovered that it no longer resembled the landscape painting by Eugen von Guerard, which he had commissioned in 1855, and he publicly protested. Tower Hill, he maintained, was 'intended by Nature to be a public park, and a place of pleasure for the people of the district' (Bonyhady, 2000: 341). Dawson published his impressions in the Camperdown Chronicle on Tuesday 24 February 1891:

Sir.-In the early days of this colony there was to be seen between Port Fairy and Warrnambool, one of the most beautiful and interesting specimens of an extinct Volcano in all Victoria, "Tower Hill and Lake," then in their primitive state, attracted my attention so much, that, fortunately for future generations, I commissioned a celebrated artist to paint the scene in oil on a large scale, and he carried out my wishes faithfully and beautifully. On visiting the cone lately, I was amazed and disgusted to find everything altered; the fine trees on the cones and in the craters of the island all gone excepting half a dozen or so. But what was a thousand times worse than this ruthless destruction of ornamental timber, the larger portion of the lake is made into a seething, stinking, mud-pool, full of fermenting malarious matter, sufficient to poison the whole neighbourhood, and which to prevent any sensible person settling near it. Our inquiry was informed that this disgraceful and unsavoury pollution of a pure lake was the work of the inhabitants of the village of Koroit, who, to save trouble in getting rid of their foul matter by its legal and natural, excuse of drainage, deliberately shunted by their neighbours by means of a tunnel through the bank of the lake; thereby polluting its water, and causing a state of matters which very soon will prove fatal to the health of the locality. Since I visited the "mud pond" I have been informed that the people of Koroit derive their chief supply of water, by means of a pipe from a pump well sunk in the inner bint of the lake, close to the mouth of the tunnel. If this information is correct, who can be astonished at the spread of malarious diseases?-Yours, etc, JAMES DAWSON.

He published a second letter in the Camperdown Chronicle on Tuesday 10 March 1891:

Sir, While lately in Melbourne I received copies of the Camperdown Chronicle of the 24th Inst., entertaining my letter on the disgraceful treatment of "Tower Hill and Lake." in the Western district, by the ruthless destruction of the timber on the island, and the discharge of the fermenting filth and sewage of Koroit by tunnel into the lake, thereby producing such a state of matters us will shortly produce a pestilence in the neighbourhood, besides damaging the water supply of Koroit, which I was informed on good authority is obtained from a well within a few yards of the inner mouth of the tunnel. Determined that this important matter should be brought under the notice of the proper authorities and investigated, I had interviews with the Secretary of Lands, and Secretary of the Board of Health, and on stating my own observation on the state of the lake, accompanied with copies of my letter published in the Chronicle, these gentlemen gave me an assurance that there would be an inquiry, which I hope will be hold while the hot season lasts. Yours, etc. JAMES DAWSON. 
Dawson published a third letter in the Camperdown Chronicle on Tuesday 7 April 1891:

\begin{abstract}
SIR, - On the 24th ult., you kindly published a letter from me with the above title, setting forth unwarrantable destruction of the fine trees on the island, but what was a thousand times worse, the diverting the drainage of Koroit into Tower Hill lake, by means of tunnel cut through the bank, thereby converting it into a stinking, seething mud-pool. This was replied by the Koroit Sentinel in leading article as follows: "We fail to see what reason there is for making such an unfounded attack on the inhabitants of Koroit, as has been done in the letter alluded to, and we advise persons who wish to attack the district, to take the trouble to get some information about it, and not be in haste to print statements that are as absurd as they are untrue. In accordance with the advice of the writer of that article I again very recently visited the locality, and I found abundant corroboration of my information concerning the drainage of Koroit. It appears to be unquestionable that the only drainage of miles of roads, streets, and by ways, is directed into Tower Hill Like, and nowhere else, with the result, that the lake is not only a seething mass of fermentation at the end next to the tunnel, but the water at the other end is very bad, where pure water, might have been expected. The writer then says that "it is only after heavy rain that any water runs through the tunnel, and then only clean water," and as a proof of its purity, he mentions that "a sample of the water as it ran through the tunnel into the lake was forwarded to Melbourne in 1886 for analysis by the inspector of nuisances, and done so privately, that neither the borough councillors nor any of the officials, except the inspector of nuisance had any idea that the analysis was being made." The report of the analyst stated that "the water was pure rain water, with a certain amount of mud in solution, but no offensive matter." On this as above described "so privately" obtained sample of water in 1886 said 'report' was founded, and is now quoted to prove the purity of the drainage in 1891, and notwithstanding the increase of population and traffic since 1886 is still made an excuse for the perpetuation of a nuisance. For further information on the treatment of Tower Hill and Lake, I refer the writer of the leader in the Koroit Sentinel to previous correspondence on the subject.-Yours. \&c, JAMES DAWSON, Local Guardian of Aborigines, Camperdown.
\end{abstract}

Dawson was eighty-four and in poor health in 1891, and must have expected that his letter would be read in Koroit, where the local Sentinel newspaper admitted it knew nothing of von Guerard's painting, but otherwise accused Dawson of making 'not one true statement'. The Sentinel maintained that the trees on the islands had been destroyed by fire rather than felled. There also was 'not the slightest miasma from the lake': the drain simply carried storm water, and the local council exercised the 'greatest care' to ensure 'no offensive matter' ran into it (Bonyhady, 1987: 343). By then, Dawson had gone directly to the colonial government. On a visit to Melbourne, he arranged interviews with the Secretary of Lands and the Secretary of the Board of Health, and persuaded them to investigate the lake (Bonyhady, 1987: 344). This activism came to nothing. Local health officers replied that the state of the lake was due to a 'natural drying-up process'; the drain carried only storm water after heavy rain and no one living on the lake bank had suffered a serious illness in seven years. But within a few months, local residents were also protesting about 'offensive matter' going into the drain. Later accounts make clear that the town's waste sometimes reached the lake, justifying Dawson's insistence that it was a 'seething swampy lagoon, supplied 
through two tunnels with the sewage of the town of Koroit, and the numerous farms in the district' (Bonyhady, 1987: 344).

When ownership of the Sentinel changed in late 1891, its new proprietors made much of the 'beautiful natural monument' at Tower Hill because it was one of Koroit's 'most popular places of resort', and they fancied that it could assist Koroit to be chosen as the new national capital when Australia became federated. They also acknowledged that Tower Hill's 'beauty and loveliness' had, at least temporarily, been 'ruined': its wildfowl driven away by professional shooting on the lake needed to be restricted, if not banned, and urged the local council to restore Tower Hill's trees (Bonyhady, 1987: 345).

Six month later, the local member, Sir Bryan O’Loghlen, introduced a Bill to vest the lake and islands of Tower Hill in the council, which he hoped would 'restore the spot to its pristine beauty'. O'Loghlen underlined this idea by calling his legislation the 'Tower Hill National Park Bill'. The press in Koroit and Warrnambool agreed that national parks were the only means of persevering 'the indigenous trees, shrubs and flower of our island continent'. Yet the vesting of Tower Hill in the council was never likely to lead to its protection, let alone restoration, because Koroit was accustomed to exploiting it. Although formally a reserve for public recreation, in 1891 it served as a town common where every ratepayer could depasture five head of stock. When the Sentinel called for the replanting of Tower Hill, the council responded by setting fire to one of the islands. Its object was to remove the undergrowth, which reduced the feed available for grazing and was 'a great harbour for rabbits'. But the blaze left 'hundreds of burning stumps' (Bonyhady, 1987: 345).

In 1892, it became Victoria's first National Park in recognition of its unique features, but wasn't managed as a National Park as people still continued to farm and quarry there. The Tower Hill National Park Bill was passed on 5 December 1892, vesting Crown land at Tower Hill in the control of the Borough of Koroit. The area was to be maintained as a park for public recreation purposes. This was the first 'National Park' in Victoria, but it was not in the style of present day national parks. O'Loghlen's Bill was also flawed. Rather than defining a 'National Park' as a place to be preserved or rehabilitated, it simply vested Tower Hill in the council 'as a park for public recreation purposes'. The bill also did not address how the restoration of Tower Hill might be paid for; the council's receipts from grazing on the island were insufficient to pay for a ranger, let alone clear the islands of its rabbits, which had already survived fires, a Saturday shoot by local residents and burrows filled with poisoned gas (Bonyhady, 1987: 345).

Although the Tower Hill National Park Act 1892 stipulated that Tower Hill could be used for 'no other purpose whatsoever' than public recreation, the Council turned it into a quarry, using its scoria as 'road metal' and its tuff for gravel. Although there were many other deposits of scoria and tuff nearby, Tower Hill became the main local source for road-making. By 1894, there were seven pits-three in the national park, the other four on private land-leaving great gouges in the crater and islands. Koroit 
was probably also to blame for the disappearance of the lake on the eastern side of the islands. The water level in the lake started dropping almost as soon as the council began tapping the main spring in 1890; then the lake dried up for extended periods before finally disappearing altogether during the drought of 1914, allowing stock to graze unimpeded on the islands (Bonyhady, 1987: 345). Tower Hill remained firmly under the control of the Koroit Council, which continued to allow grazing and quarrying in the park for many years.

\subsection{Third Phase: Enshrinement 1892-Present}

MacCannell identified enshrinement as the third phase. This occurs when there is an increase in tourism numbers and the reputation of the attraction is enhanced 'when the framing material' itself becomes integrated into the sight.

The Horsham Times (17/12/1895) reported on the state of tourism at Tower Hill in the 1890s:

TOWER HILL: A drive to Tower Hill is usually the first proposition to a tourist, and it is one which will repay the journey. The visitor leaves Warrnambool by the Belfast Road, passing through the township of Dennington, about three miles distant. After Dennington bridge has been crossed, the magnificent pastures of Farnham Survey are passed, occupying the road on either side. Passing the hilly and sinuous road through the estate, the visitor detects his emergence into the volcanic region of Tower Hill. In the cuttings of the road may be seen layers of ashes belched forth by the volcano in its igneous activity. The Vagabond says of this piece of natural scenery: A 10-mile drive from Warrnambool, and we are on the banks of Tower-hill lake. This is six miles in circumference, deep in some places, and abounding in eels; sedgy and marshy in other, the banks bordered with reeds and dead gum trees. The extinct volcano is an island, or rather three islands in the centre of this lake, or moat, which has been formed by the wall of ashes thrown up by the active crater, the accumulation making a circular bank almost as high as the volcano itself. The island is a public reserve of some 600 or 700 acres, a temporary crossing place making it available for tourists and picnic parties. Climbing the hills, one can study the old craters or inspect the small pool, a miniature edition of "Paradise Lake," on the island in Wanaka, New Zealand. From the highest point of the island the site of the old trignometrical station, the most extensive view is obtained, but from the road round the lake bank one has just as grand a coup d'oeil..$^{33}$ The waters of the lake are 25 feet below us: the banks all covered with verdure, sheep grazing to the very edge. From the Grampians to the white-fringed seashore, on all sides distant outlines of hill and mountain, enclosing it glorious view of plain and valley, of flowing streams, wooded dells, green meads, fertile paddocks, with pleasant homesteads and prosperous townships dot- ted here and there. A grand magnificent view this I question if I shall see such another panorama in Australia. From Beechworth, from the Alps, from Mount Major and Mount Hope, I have been privileged to view something of Victoria, but the country around Tower-hill possesses, besides the adjuncts of mountain and plain, wood, water, and sea, a special interest of its own."

33 A French expression that means a glance, glimpse, or a quick look. 
From Tower Hill, the visitor should drive on to Koroit, a flourishing town in the centre of the rich agricultural land, and a pleasant half-hour can be spent by visiting the Koroit Botanical Gardens.

The degradation of Tower Hill was exacerbated by the first significant attempts at treeplanting, which added Monterey pines to the crater's bank. After the town's United Friendly Societies' Committee persuaded the council to obtain trees from the State Forests Commission, local school boys planted 600 pines in 1924, which flourished behind a protective fence. The schoolboys knew that 'when the early pioneers first came to settle near Tower Hill' it had been 'a real Australian wonderland', its banks covered with 'beautiful trees-ferns, hazel and musk bushes'. Despite their very different plantings, they saw themselves as recreating this 'well-wooded' past and enhancing the future. In an essay in the local school magazine one of the boys declared, 'We shall watch their growth with interest....for we feel sure that what we are doing will be of great benefit to those who come after us'. Other local residents wanted native trees. P.E. O'Grady, a Warrnambool accountant, exclaimed in 1937, 'What a wonderful scene could be recreated if Tower Hill...was replanted with native timber!' He thought the Warrnambool Rotary Club would help because it was 'interested in all tree-planting schemes' (Bonyhady, 1987: 355). However years later the Australian Natives' Association planted a stand of manna gums, the staple source of food for koalas in southern Australia. The Association wanted to establish a chain of koala colonies through Victoria, where the fur trade, habitat destruction and disease had reduced the koala population to perhaps 500 in 1925 . But rabbits burrowed under the protective fence and killed almost all the trees within a year, so the council reverted to planting pines and willows.

When the National Parks Act was introduced in 1956, Tower Hill was omitted because of its degraded condition. It had been virtually stripped bare and little wildlife remained. The Warrnambool Field Naturalists Club held its inaugural meeting in March 1958. In February 1959 the Field Naturalists requested one acre to be planted in native trees which was granted. It was the initial step in a program to restore Tower Hill to its former beauty (John, Moore \& Moore, 1992).

In May 1960, Victoria's new State Wildlife Reserves Investigation Committee approved to transfer Tower Hill to the Fisheries and Wildlife Branch as Victoria's seventh Game Reserve. Four months later this decision was law and Victoria's first national park no longer. Alienation of parts of Tower Hill began at an early date and since 1961 it has been necessary for the Government to purchase back more than 110 acres of the banks. A considerable length of the bank of Tower Hill remains in private control (John et al., 1992: 8).

The Fisheries and Wildlife immediately stopped quarrying and grazing within the reserve and appointed two bailiffs, who began poisoning foxes, eradicating noxious weeds such as boxthorn and thistles, and attacking the islands' rabbits, which were the primary obstacle to the growth of new trees. They were also quick to try to control the use of private land both within and outside the crater. In 1961 it infuriated local 
councils and landowners when the Fisheries and Wildlife persuaded the government to make an interim development order giving Victoria's new Town and Ocean Planning Board control over the area between Tower Hill and the ocean. While this order did not affect the quarries already operating on private land, it required the Board's consent for all new land uses, including subdivision and the opening of further quarries. At the same time, the Branch sought to buy up and close the existing quarries. By early 1962 it had acquired seventy-four aces on the craters eastern banks; by 1966 only one quarry was still operating (Bonyhady, 1987: 355).

The Department of Fisheries and Wildlife was quick to publicise its work. Even in 1960, before it actually took charge of the old national park, it published the first of a series of pamphlets by Downes in which he cast Tower Hill as 'a monument to...the destruction of vegetation and wildlife which resulted from settlement of Victoria by the white man' and emphasised 'the opportunity...to bring this area back to something approaching its original condition'. In 1962 the Department worked with the Country Roads Board and the Tourist Development Authority to construct a new lookout on the Princes Highway overlooking Tower Hill. Donations were received from 1962 to commission architect Robin Boyd to sketch plans for a natural history centre. The purpose of the centre was to show the public how wildlife reserves conserved wildlife and to provide details of the conservation work and the historical records of Tower Hill, and the early settlers who tried to preserve it. In 1964 the Department re-established access to the islands by rebuilding the causeways, which had been submerged in the 1950s (Bonyhady, 1987: 356).

Once Tower Hill was declared a State Game Reserve under the Wildlife Act in 1961, the Fisheries and Wildlife Division was responsible for the management and replanting programme which commenced in 1961. When Tower Hill was declared a State Game Reserve in 1961, the then fisheries and Wildlife Division of the Victorian Ministry of Conservation embarked on a restoration program based on Von Guerard's painting. The painting was so detailed that a naturalist, J Ros Garnet, was able to identify at least twelve plant species. The artist's vision was used as a template for the restoration. In the eighteenth century, landscape gardeners such as Capability Brown created artificial wildernesses based on paintings of Claude and Poussin. In Australia, scientists scrutinised von Guerard's brushstrokes and turned art into nature (Griffiths, 1991:21).

Max Downes serendipitously discovered the von Guerard painting in 1960 when he went to Melbourne to visit Mrs K.P.M. Winter, the daughter of Isabella Dawson, and granddaughter of James Dawson. The painting had been commissioned by James Dawson to show the vegetation 'as the Aborigines knew it and just before the Europeans ruin it' (Ryllis Clark, 1996). The fact that von Guérard was a botanist meant that he had a very good eye for the detail of the vegetation, and this has greatly aided the planting programme. Botanists studied the painting to identify plants, and replanting was based on species known or believed to have been indigenous to Tower Hill. For six years Von Guerard's painting was displayed at the Natural History Centre 
at Tower Hill. The Branch decided that the centre was too insecure to house the painting which jumped in value in the 1970s as von Guerard came to be regarded as one of Australia's finest colonial artists. As a result, the Branch decided to loan it to the Regional Gallery in Warrnambool where it was soon surrounded by new paintings of Tower Hill (Bonyhady, 1987: 363).

The Fisheries and Wildlife Department developed a planting scheme using von Guerard's detailed painting as a reference as it shows grasses and ferns on the island, and tea trees, wattles, she oaks, banksia and eucalypts on the cones with reeds and tussocks in the marshes.

By 1981, around 25,000 trees and shrubs had been planted with the help of school children and volunteers along with herbs, grasses and rushes. As the plants became established, introduced plants and weeds were removed. More recently, Parks Victoria conducted a pollen analysis at Tower Hill which helped identify other plants growing before European settlement (Parks Victoria, 2012).

Community involvement has been a critical part of the re-vegetation and redevelopment of Tower Hill over the last 50 years. It is an integral part of the local Warrnambool, Koroit and Killarney communities and local stakeholders feel strongly about its long term future.In 1992, 'The Friends of Tower Hill group' was established. The group meets for a working bee each month and is joined by Parks Victoria representatives. In 2012, The Moyne Gazette (2012) reported that 'The Friends of Tower Hill' is still going strong two decades later with an active membership of 10 as well as a number of other members who live outside of the area'.

In 2002, the Worn Gundidj Aboriginal Cooperative entered into a Commercial Services Agreement with Parks Victoria to provide visitation experiences, tourist information and saleable items at Tower Hill Wildlife Reserve. Worn Gundidj volunteers with their technical expertise and horticulture resources liaise with schools that are actively engaged in Tower Hill revegetation programs. Worn Gundidj also facilitated a Natural Heritage Trust program that resulted in some ten thousand units being planted and guarded at Tower Hill. On the tourism front they are product partners of the Great Southern Touring Route offering fun-filled and informative activities ranging from Kids Games to Aboriginal history and Environmental Science. Worn Gundidj Aboriginal Cooperative, with Parks Victoria, has revitalised Tower Hill. 'The most important thing at Worn Gundidj is to reinvigorate the culture and storylines of our people,' says John Collier, Executive Chairman of the Cooperative. 'We take a holistic approach to the area. Not only do we do interpretative tours, but we're involved in conservation, tree planting and looking after the natural habitat. Indirectly that transfers skills to our guides' (Australian Traveller, 4/3/2008). 


\subsection{Fourth Phase: Duplication}

MacCannell's (1976) fourth phase in the development of attractions is that of 'duplication', when copies of the nucleus of the attraction, in this case the caldera, are made available through media such as paintings, photographs, and postcards.

The most famous duplication of Koroit or Tower Hill is the 1855 oil painting by Eugen von Guerard, entitled 'Outlook' which today is housed at the Warrnambool Regional Art Gallery. Printed reproductions of 'Outlook' were made by Thomas McLean of London and carried the caption 'View of Moroit [sic] or Tower Hill. Extinct volcano between Lady Bay and Port Fairy in Australia Felix. The original in the possession of James Dawson Esq. of Kangatong' (Downes, 1961: 32). Other significant duplications include a sketch by Bonwick in 1857 (Bonwick, 1858); a series of four paintings in 1867 by Daniel Clarke of Warrnambool (Downes, 1961: 37). For a more complete list of paintings and early photographs see Downes (1961).

In the case of Tower Hill, the interpretive centre, now known as the Worn Gundidj Visitor Centre, on the main island, duplicates the caldera in its design. The centre was completed around 1970 and was designed by Melbourne architect Robin Boyd. The building is designed in the shape of a volcanic cone and has displays of geology, flora, fauna and human history (including Aboriginal dress) of Tower Hill (see Fig.8.3). The Centre also sells souvenirs and products such as bags, napkins, tea-towels made by the local Worn Gundidj Aboriginal Cooperative. These products are also available online. The Centre is run by the Worn Gundidj Cooperative in conjunction with Parks Victoria.

\subsection{Fifth Phase: Social Reproduction}

For MacCannell, the final stage of sight sacralization is social reproduction which 'occurs when groups, cities, and regions begin to name themselves after famous attractions'. In the case of Tower Hill, social reproduction has occurred in the naming of a local accommodation business - 'Tower Hill House', Tower Hill Boutique Lavender and Oil Farm. The local caravan park employs both names: 'Koroit-Tower Hill Caravan Park'. In terms of the traditional Aboriginal name for Tower Hill, that of Koroit, this name has been reproduced in present usage in the nearby township of Koroit which dates from 1857 and the borough of Koroit; Koroit Art Gallery; Mickey Bourkes Koroit Hotel, and other businesses and organizations.

\subsection{Tourism at Tower Hill}

From a state-wide tourism view point, Tower Hill is generally regarded as a secondary attraction in the overall Great Ocean Road tourism product, particularly in relation 
to Port Campbell National Park. However, at a regional and local level, Tower Hill is a very important attraction. In terms of on-site self-guided walks, the reserve has five walks - each with different themes: Peak Climb - Orientation and geology; Lava Tongue - Boardwalk wetlands and wildlife; Hat Island - Habitat track revegetation; Whurrong Walk - Wetlands and habitat; and Journey to the last volcano - geology and wildlife. The reserve also offers picnic facilities, promotes wildlife viewing; and has the Worn Gundidj Visitor Centre that promotes Aboriginal and natural heritage of the reserve. Visitors are able to gain access to the park at all times, with the Visitor Centre being open at set times. The visitor centre is a not for profit organisation, the Visitors Centre is managed to ensure that visitors have a high quality experience and ensure that the facilities are well maintained. It is also possible to have guided experiences that centre on Aboriginal history; Wildlife encounters; Volcano and nature walks; Night adventure treks; and the centre is able to be booked to host birthday parties for children; and offers interpretive classes on understanding nature for children/school groups.

The Department of Sustainability and Environment (DSE) has the role of ensuring the sustainable management of natural and cultural resources for both current and future generations. Parks Victoria is responsible for the planning and management of Victoria's parks and reserves systems including Tower Hill. Both agencies realise that tourism can provide a vehicle for maintaining the natural and cultural assets, while meeting the needs of Victorian residents. It was suggested by Parks Victoria that the name Tower Hill State Game Reserve should be changed to either Tower Hill Volcanic Reserve or Tower Hill Heritage Park, as it was thought that a more appropriate name would be better for marketing, however, in 2013, the name is still Tower Hill State Game Reserve.

The Worn Gundidj Aboriginal Co-operative Ltd commenced operation in 1992 and along with Parks Victoria began the management of the Visitor Centre in the same year. Worn Gundidj Aboriginal Cooperative aims to achieve the following goals: Tourism-the operation of tours and a Visitor Centre at Tower Hill State Game Reserve near Warrnambool, Victoria; and Horticulture - a nursery that generates sales of potted colour and native plants, and environmental rehabilitation and services.

Tower Hill is also part of the UNESCO endorsed Kanawinka Geopark. The Kanawinka Geopark, named for Kanawinka, "Land of Tomorrow", is situated along a structurally controlling geological fault of the same name that extends from the Narracoorte Caves in South Australia into Western Victoria, before disappearing offshore at Portland.

In 1953, The Argus (5/5/1953) reported on the tourism possibilities at Tower Hill, and noted that local residents compared it with American canyons and New Zealand hot springs. 
Table 8.2 presents a chronology of major developments at the site:

Tab. 8.2: An Historical Timeline of Tower Hill

\begin{tabular}{|c|c|}
\hline Date & Event \\
\hline $30,000 \mathrm{BC}$ & $\begin{array}{l}\text { Volcanic eruption / formation. This was eventually followed by natural } \\
\text { revegetation. }\end{array}$ \\
\hline Until approximately 1840 & Used by the Koroitgundidj people and their descendants \\
\hline 1802 & $\begin{array}{l}\text { First confirmed European sighting (Captain Baudin aboard the Geog- } \\
\text { raphe) }\end{array}$ \\
\hline 1840 & First Occupation by pioneer graziers (clearing commences) \\
\hline 1855 & Eugen von Guerard painted ‘Outlook’ \\
\hline 1892 & $\begin{array}{l}\text { Declared Victoria's first 'National Park' by local council (but not } \\
\text { managed as such) }\end{array}$ \\
\hline Mid 1950s & $\begin{array}{l}\text { Grazing, quarrying, crop growing and rubbish dumping continue until } \\
\text { the hills and island are bare and little wildlife remains. Duck shooting } \\
\text { was also allowed. } \\
\text { Extensive lobbying for revegetation including efforts by the Warrnam- } \\
\text { bool Field and Game Club and the Warrnambool Field Naturalists Club. }\end{array}$ \\
\hline 1961 & $\begin{array}{l}\text { Declared a State Game Reserve under Wildlife Act. Fisheries and } \\
\text { Wildlife Division responsible management. Replanting program com- } \\
\text { mences. Over 300,000 trees planted with the help of conservation, } \\
\text { community groups and schools. } \\
\text { Tower Hill becomes recreation and conservation asset for the local } \\
\text { community and for visitors. } \\
\text { Site is significant for interpretation and education. }\end{array}$ \\
\hline $1969 / 70$ & $\begin{array}{l}\text { Robin Boyd-designed Centre constructed. Series of interpretive dis- } \\
\text { plays subsequently installed. }\end{array}$ \\
\hline 1997 & $\begin{array}{l}\text { Parks Victoria became responsible for management. Managed under } \\
\text { Wildlife Act. }\end{array}$ \\
\hline 2002 & Commissioning of the Tower Hill Future Directions Strategy. \\
\hline
\end{tabular}

In December 2013, Worn Gundidj Aboriginal Cooperative announced the release of a new tourism package centred on Tower Hill, called an 'escape package', which is focussed on the region's Indigenous culture, landscapes, historic shipwrecks, volcanoes and native animals. The package includes a guided bushwalking 'walk with wildlife' tour through the reserve at night, which gives visitors the chance to experience Tower Hill's silhouetted crater and landscape at sunset as well as the night time nature walk (Tourism Australia, 2013). 


\subsection{Conclusion}

Tower Hill as a tourism attraction has significant natural values for local and international visitors. It became a tourist attraction more for its natural significance rather than its Indigenous values, although visitors to the site are able to learn about the Indigenous people and their way of life. Tower Hill is one of the first natural features in Victoria to be given a European name 'Peak of Reconnaissance' in March 1802 by the French explorers Baudin and Peron. A nested caldera, it is one of the most recently active volcanoes in western Victoria, and a well as these significant natural values it has significant Aboriginal heritage values as represented in the detailed Aboriginal microtoponymy that has been recorded in the ethnographic record. The name Tower Hill is descriptive and is believed to date from 1838. Although European settlement and land use began from this time, portions of the caldera remained as Crown Land and in 1866 local residents were successful in their endeavours to reserve Tower Hill when the Victorian Government declared it the Tower Hill Acclimatisation Reserve. When schools inspector James Bonwick visited the site in 1857 he considered it sublime and grand and urged its reservation. Two years previously, local settler James Dawson had commissioned German landscape painter Eugen von Guerard to paint Tower Hill. Years later, in 1961, this most famous example of duplication of the site featured prominently in attempts to restore the vegetation of the island to that depicted in the von Guerard painting. In 1892, Tower Hill became Victoria's first National Park and was maintained as a park for public recreational purposes by the local shire council. However, continued environmental degradation of Tower Hill led to its omission from the 1956 National Parks Act. Local Field Naturalists were responsible for efforts to arrest the degradation and take active steps towards its environmental rejuvenation. In 1960 Tower Hill became victoria's seventh Game Reserve, and the government department responsible, the Department of Fisheries and Wildlife set about establishing a natural history centre and embarked on a restoration program based on von Guerard's painting (see Fig.8.4). This chapter has given an historical analysis of Tower Hill State Game Reserve, documenting its evolution from when Europeans inhabited the Reserve to the present day where it has been rejuvenated and become a favourite attraction for locals and visitors to the area.

\section{References}

Australian Plans Online. (1996). Retrieved January 2, 2013, from The Tower Hill Experience: http:// anpsa.org.au/APOL2/jun96-2.html

Australian Traveller. 4/3/2008

Australian Traveller. (2012). Retrieved December 5, 2012, from Australian Traveller: http://www. australiantraveller.com/warrnambool/worn-gundidj/

Bonyhady, T. (1987). The Colonial Image. Chippendale: Ellsyd Press.

Bonyhady, T. (2000). The Colonial Earth. Melbourne: Melbourne University Press. 
Bonwick, J. (1858). Western Victoria; its geography, geology and social condition. The narrative of an educational tour of 1857. Geelong: Thomas Brown.

Brady, A. (2012, October 18). Retrieved January 9, 2013, from Moyne Gazette: http://www. moynegazette.com.au/story/402890/friends-of-tower-hill-to-improve-facilities/

Camperdown Chronicle, 24/2/1891; 10/3/1891; 7/4/1891

Community South West. (2010, June 9). Retrieved December 5, 2012, from Worn Gundidj Cooperative: http://www.communitysouthwest.com/membership/worn-gundidj

Clark, I.D. (1990). Aboriginal languages and clans: an historical atlas of western and central Victoria, 1800-1900. Melbourne: Department of Geography and Environmental Science, Monash University.

Clark, I.D. (ed.) (2000a). The Journals of George Augustus Robinson, Chief Protector, Port Phillip Aboriginal Protectorate, Volume One: 1 January 1839-30 September 1840. Clarendon: Heritage Matters.

Clark, I.D. (ed.) (2000b). The Journals of George Augustus Robinson, Chief Protector, Port Phillip Aboriginal Protectorate, Volume Three: 1 October 1841-31 December 1843. Clarendon: Heritage Matters.

Clark, I. D., \& Heydon, T. (2002). Dictionary of Aboriginal Placenames of Southwest Victoria. Melbourne: Victorian Aboriginal Corporation for Languages.

Clark, I.D. (2009). Reconstruction of Aboriginal micro-toponymy in western and central Victoria - case studies from Tower Hill, the Hopkins River, and Lake Boga. In H. Koch \& Hercus, L. (eds), Aboriginal Placename: Naming and re-naming the Australian Landscape (pp. 207-221). Canberra: Aboriginal History Inc. \& ANU E Press.

CPG. (2011). Koroit Strategy Plan: Context Report. Moyne Shire Council. Retrieved January 6, 2013, from http://www.moyne.vic.gov.au/Files/Draft_Koroit_Context_Report_March_2011_version.pdf

Dawson, I.P. (1870). The language of the Aborigines, letter to the editor. The Australasian. 19/3/1870.

Dawson, J. (1881). The Australian Aborigines: the languages and customs of several tribes in the Western District of Victoria, Australia. Melbourne: George Robertson.

Destination Recovery Services. (2007). Retrieved January 9, 2013, from http://www.destinationrecovery.com/destinationlifecycle.html

Downes, M.C. (1961). The History of Tower Hill to 1892. Koroit: Fisheries \& Wildlife Division, Tower Hill State Game Reserve.

Fisheries and Wildlife Department. (1983). Tower Hill State Game Reserve. East Melbourne: Ministry for Conservation.

Griffiths, T. (1991). History and Natural History: Conservation Movements in Conflict. History and Natural History, 24(96): 16-32.

Horsham Times, 17/12/1815

Illustrated Australian News, 21/3/1883

Learmonth, N.F. (1934). The Portland Bay Settlement being the history of Portland, Victoria from 1800 - 1851. Portland: The Historical Committee of Portland.

Kanawinka Global Geopark (2010-2012). Retrieved January 9, 2013, from: http://www.kanawinkageopark.org.au

MacCannell, D. (1999). The Tourist. Los Angeles: University of California Press.

McCorkell, H. A., \& Yule, P. (1999). A green and Pleasant Land-A history of Koroit. Warrnambool: Collett, Bain \& Gaspar.

John, C., Moore, H., \& Moore, R. (1992). Redressing the Volcano: the Restoration of Tower Hill. Tower Hill: Tower Hill Press.

Mulder, J.F. (1909). Stone Implements of the Natives of Victoria, and their Age. The Geelong Naturalist. Second Series. 4(1): 8-14. 
Museum Victoria. (n.d.). Retrieved January 9, 2013, from Collections: http://museumvictoria.com.au/ collections/themes/1948/eugene-von-guerard-artist-1811-1901

National Gallery of Victoria (n.d.). Retrieved January 9, 2013, from: http://www.ngv.vic.gov.au/ whats-on/exhibitions/exhibitions/eugene-von-guerard

On My Doorstep. (2010). Retrieved January 2, 2013, from http://www.onmydoorstep.com.au/ heritage-listing/14278/tower-hill-state-game-reserve

Parks Victoria. (2012). Retrieved December 5, 2012, from Tower Hill Reserve: http://parkweb.vic.gov. au/_data/assets/pdf_file/0005/315662/Park-note-Tower-Hill-Reserve.pdf

Parks Victoria. (n.d.). Retrieved December 5, 2012, from Tower Hill Reserve-History and Heritage: http://parkweb.vic.gov.au/_data/assets/pdf_file/0007/315547/Heritage-story-Tower-HillReserve-history-and-heritage.pdf

Parks Victoria Tower Hill-Culture and Heritage. (2012). Retrieved December 5, 2012, from: http:// parkweb.vic.gov.au/explore/parks/tower-hill-w.r/culture-and-heritage

Parks Victoria. (2012). Parks Victoria. Retrieved December 5, 2012, from ParkWeb: http://parkweb. vic.gov.au/explore/parks/tower-hill-w.r/things-to-do/take-a-self-guided-walk-at-tower-hill

Parks Victoria. (2012, December 5). Tower Hill Wildlife Reserve. Retrieved December 5, 2012, from Park Web: http://parkweb.vic.gov.au/explore/parks/tower-hill-w.r

Peron, F. (1809). A voyage of discovery to the southern hemisphere, performed by order of the Emporer Napoleon during the years 1801, 1802, 1803 and 1804, Vol. 1. London: Richard Phillips.

Ryllis Clark , M. (1996). Discover Historic Victoria-60 heritage places to visit. Ringwood: Penguin Books Australia.

SGS Economics and Planning,(2002). Tower Hill Future Directions Strategy. Retrieved December 5, 2012, from http://parkweb.vic.gov.au/_data/assets/pdf_file/0019/313444/Tower-Hill-FutureDirections-Strategy.pdf

Sydney Morning Herald, 13/6/1902

Taylor, J.E. (1886). Our Island-Continent: A Naturalist's Holiday in Australia. London: Society For Promoting Christian Knowledge.

Tourism Australia, (2013). Aboriginal Tourism News-Indigenous Tourism Champions - Tourism Industry News - December 2013, 5th quarterly newsletter. Sydney: Tourism Australia.

The Argus, 16/9/1865, 11/7/1882, 13/12/1884, 12/8/1891, 18/6/1938, 5/5/1953

The Australian Sketcher with Pen and Pencil, 1/5/1877

The Ballarat Star, 17/12/1869

The Moyne Gazette, 18/10/2012

Visit Warrnambool:Things to do/Tower Hill. (2012). Retrieved Deccember 5, 2012, from http:// visitwarrnambool.com.au/things-to-do/tower-hill/\#.UL6qMobw-00 


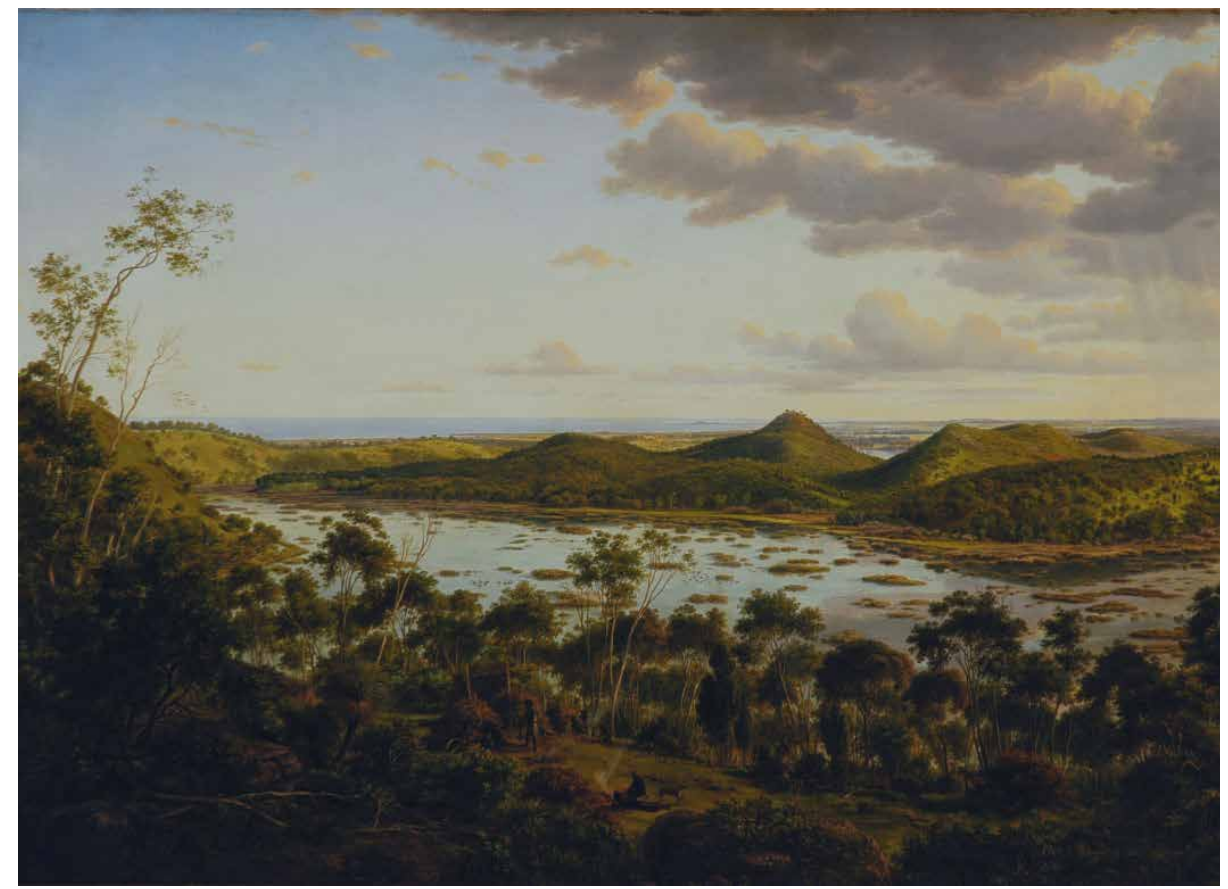

Fig. 8.1: Tower Hill

Artist: Eugen von GUERARD (b. Austria 1811, arrives Australia 1852, d. England 1901) Medium: oil on canvas

Credit line: Image courtesy of Warrnambool Art Gallery, photograph by John Brash. On loan to Warrnambool Art Gallery from the Department of Sustainability and Environment. Gift of Miss Effie Thornton 1966. 


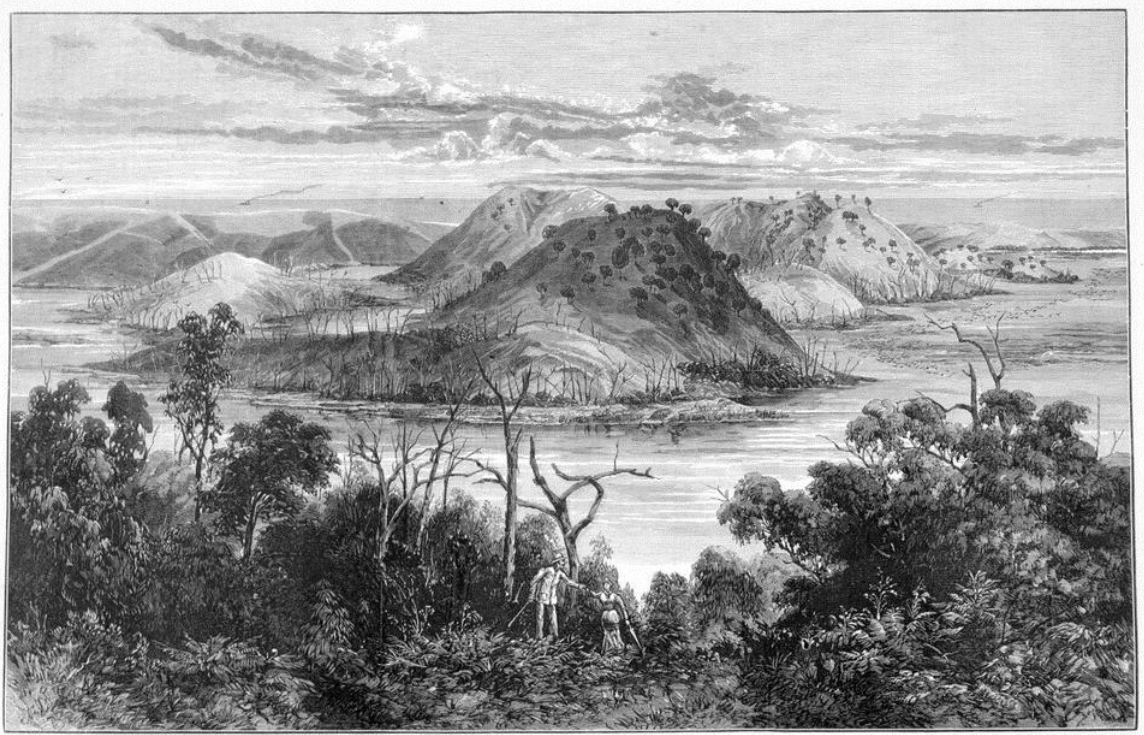

TOWKB HILL WAKR, BOBOIY

Fig. 8.2: Tower Hill Lake, Koroit, A.C. Cooke, wood engraving, Illustrated Australian News 21/3/1883.

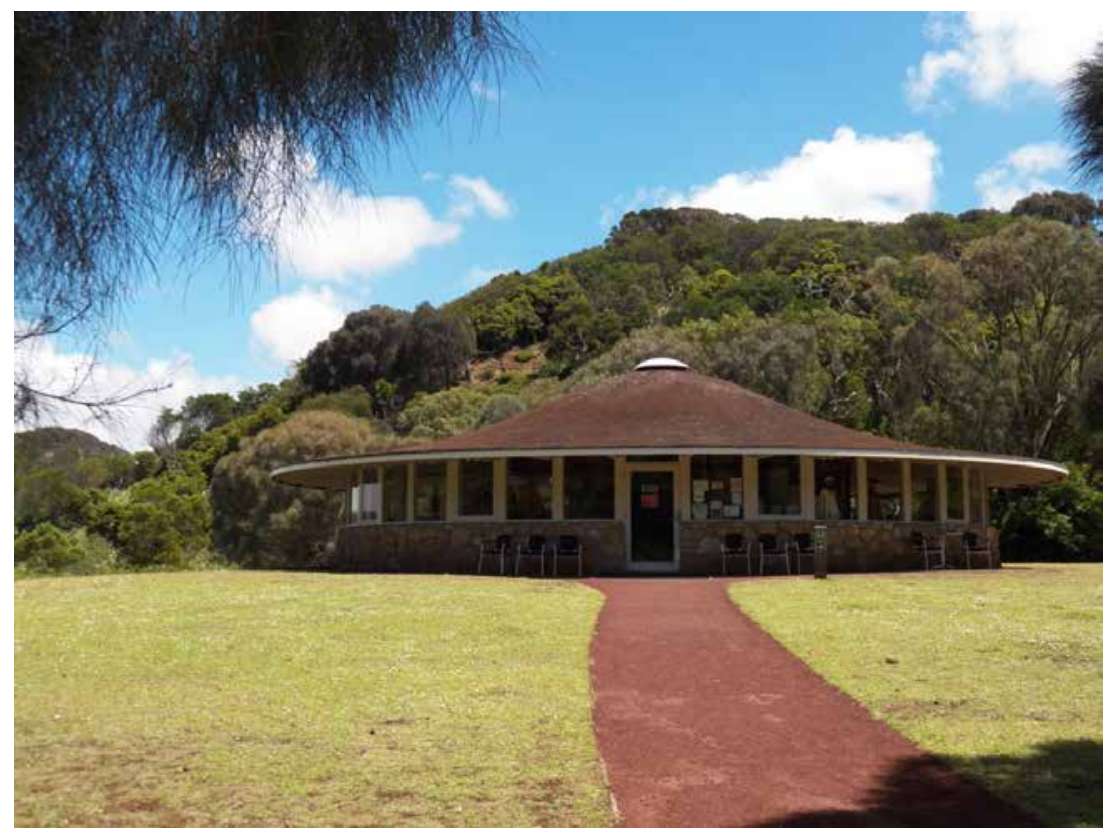

Fig. 8.3: Worn Gundidj Visitor Centre. Source: Lisa Justin 9 December 2012. 


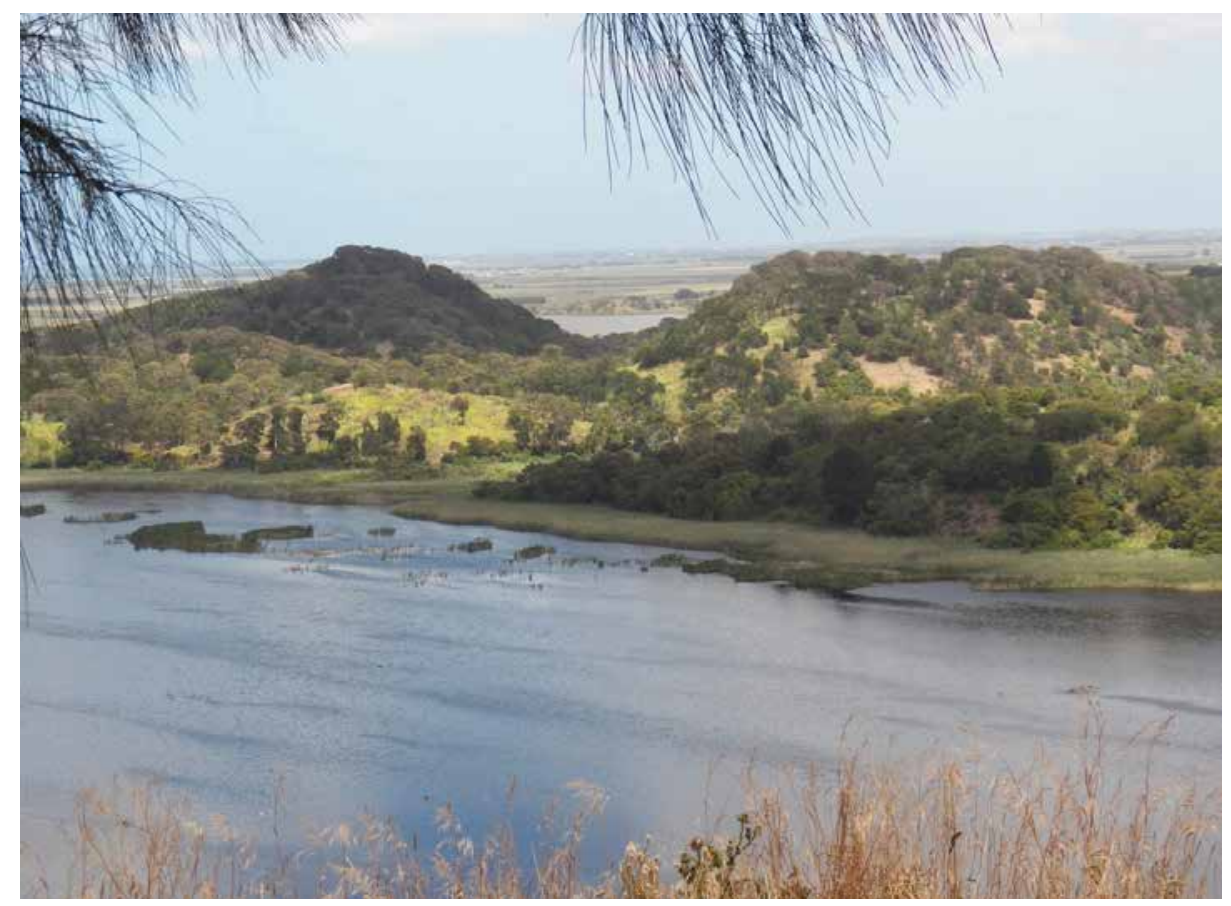

Fig. 8.4: Present view from where von Guerard painted ‘Outlook’ Source: Lisa Justin 9 December 2012. 